\title{
FUNGSI PENGAWASAN MAHKAMAH AGUNG DALAM PENYELENGGARAAN PERADILAN YANG IMPARSIAL
}

\author{
Said Sampara \\ Fakultas Hukum Universitas Muslim Indonesia Makassar \\ email : said.sampara@gmail.com
}

\begin{abstract}
Implementation of judicial power in the realization of judicial impartiality rests on their independence and the independence of judiciary in performing the duties of his judicial is not affected by any power, as well as the responsibilities imposed on judges in carrying out the task of checking and deciding cases and functions of the Supreme Court under the supervision of the judiciary the impartiality in the administration of judicial power, manifested in the form of preventive supervision, in the form of signs norms enshrined in both the legislation and the code of ethics and code of conduct of judges. In addition, there are forms of repressive supervision which in practice is carried out by the Supreme Court and the Judicial Commission.
\end{abstract}

Keywords: Monitoring \& Implementation Supreme Court Justice.

\begin{abstract}
Abstrak
Implementasi kekuasaan kehakiman dalam perwujudan imparsialitas yudisial bertumpu pada independensi mereka dan independensi kehakiman dalam menjalankan tugas-tugas kehakimannya tidak dipengaruhi oleh kekuasaan apa pun, serta tanggung jawab yang dibebankan pada hakim dalam melaksanakan tugas memeriksa dan memutuskan kasus dan fungsi Mahkamah Agung di bawah pengawasan pengadilan, ketidakberpihakan dalam administrasi kekuasaan kehakiman, yang diwujudkan dalam bentuk pengawasan preventif, dalam bentuk tanda-tanda norma yang diabadikan baik dalam undang-undang dan kode etik serta kode perilaku hakim. Selain itu, ada bentuk pengawasan represif yang dalam praktiknya dilakukan oleh Mahkamah Agung dan Komisi Yudisial.
\end{abstract}

Kata kunci: pengawasan; penyelenggaraan peradilan; mahkamah agung;

\section{A. PENDAHULUAN}

Cita-cita untuk mewujudkan kekuasaan kehakiman yang bebas, merdeka dan mandiri merupakan salah satu tujuan yang ingin dicapai dalam kerangka Negara hukum dan demokrasi. Hal ini, telah ditegaskan dalam Basic Principles on the Independence of Judiciary, yang merupakan Resolusi Perserikatan Bangsa-Bangsa (PBB) bahwa kekuasaan kehakiman yang bebas, merdeka dan mandiri adalah suatu proses peradilan yang bebas dari setiap pembatasan, pengaruh yang tidak pada tempatnya, hasutan dan tekanan atau campur tangan langsung dan tidak langsung terhadap proses peradilan. Demikian pula dalamUndang-Undang Nomor 48 Tahun 2009 Tentang Kekuasaan Kehakiman, ditegaskan bahwa kekuasaan kehakiman adalah kekuasaan Negara yang merdeka untuk menyelenggarakan peradilan guna menegakkan hukum dan keadilan berdasarkan Pancasila, demi terselenggaranya Negara Hukum Republik Indonesia. 
Resolusi Umum PBB dan Undang-Undang Nomor 48 Tahun 2009 tentang Kekuasaan Kehakiman, telah memberikan dasar pijakan bagi kekuasaan kehakiman untuk menegakkan keadilan, meskipun fakta umumnya menunjukkan adanya ketidak percayaan masyarakat pada kekuasaan kehakiman, karena adanya putusan hakim yang seringkali berpihak pada pencari keadilan tertentu, sehingga merugikan kepentingan hukum pihak lainnya.

Imparsialitas mengsyaratkan bahwa dalam menjalankan tugas peradilannya, seorang hakim hanya bertanggung jawab kepada hukum dan hati nuraninya. Seorang hakim wajib secara tidak memihak atau imparsial mempertimbangkan suatu fakta dalam perkara yang dihadapinya, dan menjalankan peraturan undang-undang atas perkara itu tanpa pengaruh dari sumber manapun.Konsep imparsialitas absolut berarti hakim harus berdiri ditengah-tengah dua pihak, tanpa mempertimbangkan tingkat-tingkat peradilan.Suatu proses peradilan yang jujur (fair trial), maka hakim itu tidak boleh dipengaruhi oleh informasi di luar berkas perkara, dan hakim tersebut harus mengadili hanya berdasarkan argumen yang dikemukakan dalam persidangan. Keadilan dalam konsep imparsial berarti memberikan putusan tanpa melihat pihak-pihaknya.Hal ini juga merupakan wujud nyata dari konsep persamaan di hadapan hukum (equality before the law).

\section{B. ANALISIS DAN PEMBAHASAN}

\section{Pengawasan Hakim Dalam Mewujudkan Peradilan Imparsial}

Sistem pengawasan hakim dalam mewujudkan peradilan yang imparsial, secara kelembagaan diselenggarakan oleh Mahkamah Agung (MA) untuk melakukan fungsi pengawasan.Dalam UU No. 48 Tahun 2009 Tentang Kekuasaan Kehakiman, mengatur pengawasan hakim dan penyelenggaraan peradilan di semua lingkungan peradilan dalam menjalankan kekuasaan kehakiman. UU No. 3 Tahun 2009 Tentang Mahkamah Agung dalam Pasal 32 menetapkan sebagai berikut :

a. MA melakukan pengawasan tertinggi terhadap penyelenggaraan peradilan pada semua badan peradilan yang berada dibawahnya dalam menyelenggarakan kekuasaan kehakiman;

b. MA berwenang untuk meminta keterangan tentang hal-hal yang bersangkutan dengan teknis peradilan dari semua badan peradilan yang berada dibawahnya;

C. MA berwenang memberi petunjuk, teguran atau peringatan kepada pengadilan di semua badan peradilan dari semua badan peradilan yang berada dibawahnya;

d. MA mengawasi tingkah laku dan perbuatan para hakim di semua lingkungan peradilan dalam menjalankan tugasnya;

e. Pengawasan dan kewenangan MA tidak boleh mengurangi kebebasan hakim dalam memeriksa dan memutus perkara;

Undang-Undang Mahkamah Agung juga mengatur pelanggaran kode etik yang mengakibatkan seorang hakim agung diberhentikan, harus dilakukan setelah yang bersangkutan diberi kesempatan untuk membela diri dihadapan Majelis Kehormatan MA.Eksistensi Majelis Kehormatan sebagai badan yang secara implisit berwenang memeriksa hakim agung, jika melanggar ketentuan-ketentuan dalam Pasal 11A UU 
Mahkamah Agung.

Pelaksanaan pengawasan yang ditetapkan dalam Pasal 32 jo Pasal 32A UndangUndang Nomor 3 Tahun 2009 tentang Perubahan Kedua atas Undang-Undang Nomor 14 tahun 1985 Tentang Mahkamah Agung, memuat dua substansi, yaitu : pertama; mengatur tentang tingkah laku dan perbuatan para hakim yang di dalam Pasal 11A lebih khusus disebut melakukan perbuatan tercela; kedua, Mahkamah Agung berwenang untuk meminta keterangan tentang hal-hal yang bersangkutan dengan teknis peradilan dari semua badan peradilan yang berada di bawahnya. Dengan demikian secara normatif ada dua kewenangan pengawasan hakim oleh Mahkamah Agung terhadap hakim-hakim di lingkungan peradilan yang berada di bawahnya.

Selanjutnya, pada Pasal 32 UU No. 3 Tahun 2009 tersebut, pada perubahannya disisipkan 2 (dua) pasal, yang salah satunya adalah Pasal 32A yang menentukan :

(1) Pengawasan internal atas tingkah laku hakim agung dilakukan oleh Mahkamah Agung;

(2) Pengawasan eksternal atas perilaku hakim agung dilakukan oleh Komisi Yudisial;

(3) Pengawasan sebagaimana dimaksud pada ayat (1) dan ayat (2) berpedoman kepada kode etik dan pedoman perilaku hakim;

(4) Kode etik dan pedoman perilaku hakim sebagaimana dimaksud pada ayat (3) ditetapkan oleh Komisi Yudisial dan Mahkamah Agung.

Dari ketentuan di atas, maka tampak bahwa kewenangan pengawasan yang harus dilakukan oleh Mahkamah Agung, adalah jalannya peradilan, dengan tujuan agar peradilan dapat diselenggarakan oleh pejabat pengadilan dengan seksama dan sewajarnya.Mahkamah Agung sebagai pengawas tertinggi atas jalannya peradilan, dapat mendelegasikan kewenangannya pada pengadilan tingkat banding berdasarkan asas sederhana, cepat dan biaya ringan. Di dalam praktek selama ini, Mahkamah Agung dalam melaksanakan pengawasan telah mendelegasikan kepada para ketua Pengadilan Tinggi di semua lingkungan peradilan, sebagaimana ditetapkan dalam Keputusan Ketua Mahkamah Agung RI Nomor: KMA:080/SK/VIII/2006 tentang Pedoman Pelaksanaan Pengawasan di Lingkungan Lembaga Peradilan, menjadi indikator keseriusan MA dalam mengoptimalkan fungsi pengawasan internal. Pada Lampiran I Keputusan MA di atas, menentukan fungsi pengawasan secara internal dilakukan oleh sebuah badan, yakni Badan Pengawasan Mahkamah Agung RI yang dibawahi langsung oleh Sekretaris Mahkamah Agung RI, dan bertanggungjawab langsung kepada Ketua Muda Pengawasan.

Pengawasan yang diselenggarakan secara internal oleh MA terdiri atas, yakni:

1. Pengawasan Internal, adalah pengawasan dari dalam lingkungan peradilan sendiri yang mencakup 2 (dua) jenis pengawasan, yaitu Pengawasan Melekat dan Pengawasan Fungsional;

2. Pengawasan Melekat, adalah serangkaian kegiatan yang bersifat sebagai pengendalian yang terus menerus, dilakukan oleh atasan langsung terhadap bawahannya secara preventif dan represif, agar pelaksanaan tugas tersebut berjalan secara efektif, dan dan efisien sesuai dengan rencana kegiatan dan peraturan perundang-undangan yang berlaku; 
3. Pengawasan Fungsional, adalah pengawasan yang dilakukan oleh aparat pengawasan yang khusus ditunjuk untuk melaksanakan tugas tersebut, dalam satuan kerja tersendiri yang diperuntukkan untuk itu. Di lingkungan lembaga peradilan, pengawasan fungsional dilaksanakan oleh Badan pengawasan Mahkamah Agung RI.

4. Pengawasan Rutin/Reguler, adalah pengawasan yang dilaksanakan oleh Badan Pengawasan Mahkamah Agung, pengadilan tingkat Banding, dan tingkat Pertama secara rutin terhadap penyelenggaraan peradilan sesuai dengan kewenangan masingmasing.

5. Pengawasan Keuangan, adalah pemeriksaan terhadap penyelenggaraan Anggaran Pendapatan dan Belanja Negara (APBN), serta dana/bantuan pihak ketiga yang sedang berjalan (current audit), dana atau yang telah direalisasikan beserta neraca (post audit) yang meliputi, Audit Ketaatan (terhadap peraturan perundangundangan yang berlaku), Audit Keuangan (dengan menggunakan standar akuntansi yang berlaku), dan Audit Operasional (apakah pengelolaan APBN telah dilakukan secara ekonomis, efisien dan efektif).

Dengan adanya pengawasan tersebut, yang merupakan upaya untuk menyelenggarakan peradilan yang imparsial dimasudkan sebagai sarana untuk :

1. Memperoleh informasi apakah penyelenggaraan tehnis peradilan, pengelolaan administrasi peradilan, dan pelaksanaan tugas umum peradilan telah dilaksanakan sesuai denagn rencana dan peraturan perundang-undangan yang berlaku;

2. Memperoleh umpan balik bagi kebijaksanaan, perencanaan dan pelaksanaan tugastugas peradilan;

3. Mencegah terjadinya penyimpangan, mal-administrasi, dan ketidak efisienan penyelenggaraan peradilan;

4. Menilai kinerja.

Adanya pengawasan yang demikian itu, maka akan tampak terlihat adanya kesesuaian antara perencanaan dan hasil capaian kinerja, sehingga menjadi sarana evaluasi untuk menilai keberhasilannya. Pengawasan yang baik tidaklah terlepas dari kinerja pelaksanaan pengawasan itu sendiri, sebagai motor penggerak utama berjalannya suatu sistem organisasi kelembagaan secara tertib dan teratur. Pengawasan adalah suatu upaya yang sistematik untuk menetapkan kinerja standar pada perencanaan untuk merancang sistem umpan balik informasi, untuk membandingkan kinerja aktual dengan standar yang telah ditentukan, untuk menetapkan apakah telah terjadi suatu penyimpangan dalam penyelenggaraan peradilan, serta untuk mengambil tindakan perbaikan yang diperlukan untuk menjamin bahwa semua sumber daya telah digunakan seefektif dan seefisien mungkin guna mencapai tujuan. Pengawasan merupakan hal penting dalam menjalankan suatu perencanaan yang pada dasarnya diarahkan sepenuhnya, untuk menghindari adanya kemungkinan penyelewengan atau penyimpangan atas tujuan yang akan dicapai. Bahkan, melalui pengawasan tercipta suatu aktivitas yang berkaitan erat dengan penentuan, atau evaluasi mengenai sejauhmana pelaksanaan kerja sudah dilaksanakan. Pengawasan juga dapat mendeteksi sejauhmana 
penyelenggaraan peradilan secara imparsial telah dijalankan, dan sampai sejauhmana penyimpangan yang terjadi dalam proses penyelenggaraan peradilan.

Dalam kaitannya dengan penyelenggaraan kekuasaan kehakiman yang akuntabilitas dan imparsialnya peradilan, pengawasan merupakan salah satu cara untuk membangun dan menjaga kepercayaan warga masyarakat terhadap kinerja aparatur peradilan dengan menciptakan suatu sistem pengawasan yang efektif, baik pengawasan intern (internal control) maupun pengawasan ekstern (external control) serta mendorong adanya pengawasan masyarakat (social control). Dalam konteks membangun dan mewujudkan peradilan yang akuntabel (accountable judiciary) guna mewujudkan adanya peradilan imparsial, maka pengawasan menjadi aspek penting untuk menjaga penyelenggaraan fungsi Mahkamah Agung sebagai lembaga pelaksana kekuasaan kehakiman berjalan sebagaimana mestinya.

Tujuan yang ingin dicapai dari proses pengawasan oleh lembaga MA, adalah agar diketahui kenyataan yang ada sebagai masukan, dan bahan pertimbangan dalam rangka menentukan kebijakan dan tindakan yang diperlukan menyangkut pelaksanaan tugas pengadilan, tingkah laku aparat pengadilan, dan kinerja pelayanan publik sangatlah menentukan arah perencanaan menuju hasil yang lebih baik. Proses pengawasan yang baik akan menjadi alat kontrol, dan penyeimbang terhadap semua proses, baik proses administrasi maupun sikap dan perilaku jajaran aparatur peradilan. Karena itu,sangat urgen adanya pengawasan preventif dan pengawasan represif yang dilaksanakan oleh lembagalembaga yang diberi kewenangan, yang sesungguhnya diarahkan pada sasaran untuk mencapai peradilan yang imparsial.

Pengawasan preventif lebih dimaksudkan, sebagai pengawasan yang dilakukan terhadap suatu kegiatan sebelum kegiatan itu dilaksanakan, sehingga dapat mencegah terjadinya penyimpangan. Idealnya, pengawasan ini dilakukan oleh internal MA dengan maksud untuk menghindari atau mencegah terjadinya penyimpangan terhadap pelaksanaan peradilan. Pengawasan preventif akan lebih bermanfaat dan bermakna, jika dilakukan oleh atasan langsung, sehingga penyimpangan yang kemungkinan dilakukan akan terdeteksi lebih awal. Pengawasan ini memungkinkan juga dilakukan oleh lembaga eksternal (pengawasan eksternal) sesuai dengan kewenangan yang ada.Sedangkan pengawasan represif adalah "pengawasan yang dilakukan terhadap suatu kegiatan setelah kegiatan itu dilakukan.'Pengawasan model ini lazimnya dilakukan setelah pelaksanaan tugas dan fungsi atas kewenangan yang ada dan selanjutnya dilakukan evaluasi untuk mengetahui kemungkinan terjadinya penyimpangan dalam penyelenggaraan peradilan.

Keputusan Ketua Mahkamah Agung RI Nomor: KMA:080/SK/VIII/2006 tentang Pedoman Pelaksanaan Pengawasan di Lingkungan Lembaga Peradilan, telah ditetapkan fungsi pengawasan, yakni:

1. Menjaga agar pelaksanaan tugas lembaga peradilan sesuai dengan rencana dan ketentuan peraturan perundang-undangan yang berlaku;

2. Mengendalikan agar administrasi peradilan dikelola secara tertib sebagaimana mestinya, dan aparat peradilan melaksanakan tugasnya dengan sebaik-baiknya; 
3. Menjamin terwujudnya pelayanan publik yang baik bagi para pencari keadilan yang meliputi : kualitas putusan, waktu penyelesaian perkara yang cepat dan biaya berperkara yang murah.

Pada pelaksanaan pengawasan tersebut, wewenang dan tanggung jawab pengawasan berada pada :

a. Di lingkungan Mahkamah Agung :

- Pimpinan Mahkamah Agung;

- Seluruh pejabat kepanitraan Mahkamah Agung;

- Seluruh pejabat struktural di Lingkungan Mahkamah Agung;

b. Di lingkungan Pengadilan Tingkat banding :

- Pimpinan pengadilan tingkat banding;

- Seluruh pejabat kepaniteraan;

- Seluruh pejabat struktural di lingkungan pengadilan tingkat banding;

c. Di lingkungan Pengadilan Tingkat Pertama :

- Pimpinan pengadilan tingkat pertama;

- Seluruh pejabat kepanitraan;

- Seluruh pejabat struktural di lingkungan pengadilan tingkat pertama.

\section{Bentuk Pengawasan Hakim Dalam Pelaksanaan Peradilan Yang Imparsial}

Sarana pengawasan bagi internal lembaga peradilan dilakukan secara hirarki yang dimulai dari tingkat MA, pengadilan tingkat banding dan badan peradilan tingkat pertama. Pengawasan tersebut, lebih ditujukan kepada para hakim dalam menyelenggarakan proses peradilan. Adapun obyek pengawasan Mahkamah Agung meliputi tiga hal, yaitu bidang teknis peradilan yang bertujuan untuk meningkatkan kualitas putusan hakim, bidang administrasi yang bertujuan untuk meningkatkan pelayanan hukum kepada para pencari keadilan, dan bidang perilaku pejabat peradilan (hakim dan pejabat kepaniteraan) yang bertujuan untuk meningkatkan pelaksanaan fungsi peradilan sesuai dengan kode etik profesi hakim.

\section{Pengawasan Internal Bidang Teknis Peradilan}

Teknis peradilan atau teknis yudisial adalah segala sesuatu yang menjadi tugas pokok hakim, yaitu menerima, memeriksa, mengadili, dan menyelesaikan perkara yang diajukan kepadanya.Dalam kaitan ini, termasuk pula bagaimana pelaksanaan putusan tersebut dilakukan.Tujuan pengawasan dalam konteks ini, adalah peningkatan kualitas putusan hakim. Pelaksanaan pengawasan di bidang teknis peradilan terhadap hakim dilakukan melalui pemeriksaan perkara, antara lain melalui eksaminasi perkara untuk mengetahui seberapa jauh hakim telah menerapkan hukum acara dengan seksama, dan sewajarnya dalam melakukan pemeriksaan perkara; 


\section{Pengawasan Internal Bidang Administrasi Peradilan}

Administrasi peradilan, adalah segala sesuatu yang menjadi tugas pokok kepaniteraan pada lembaga pengadilan (pengadilan tingkat pertama dan banding dalam lingkungan Peradilan Umum, Peradilan Agama, Peradilan Militer, dan Peradilan Tata Usaha Negara). Administrasi peradilan perlu mendapat pengawasan dari MA, karena keterkaitannya dengan teknis peradilan.Masalah administrasi peradilan penting untuk menghindari ketidaksempurnaan suatu putusan pengadilan. Dengan berlakunya Undang-undang Nomor 3 Tahun 2009 Tentang Mahkamah Agung, maka administrasi umum (administrasi kepegawaian dan keuangan) yang selama ini, menjadi kewenangan Kementerian Hukum dan Hak Asasi Manusia dialihkan menjadi kewenangan MA.

\section{Pengawasan Internal Bidang Perilaku Pejabat Peradilan}

Bidang pengawasan ini, sasarannya adalah pada evaluasi terhadap tingkah laku, dan perbuatan hakim atau pejabat peradilan. Pelaksanaan pengawasan terhadap perilaku pejabat peradilan (hakim dan pejabat kepaniteraan) dilakukan berdasarkan temuan-temuan atas penyimpangan-penyimpangan yang dilakukan oleh hakim dan pejabat kepaniteraan, baik yang berdasarkan laporan hasil pengawasan internal maupun yang berasal dari laporan masyarakat, media massa, dan pengawasan eksternal lainnya.

Dalam melaksanakan pengawasan, Mahkamah Agung juga menentukan adanya prinsip-prinsip pengawasan yang harus dipedomani oleh Badan Pengawas, Hakim Tinggi Pengawas, serta hakim pengawas di pengadilan tingkat pertama, yakni :

a. Independensi, yakni pengawasan dilakukan semata-mata untuk kepentingan lembaga peradilan, tanpa didasari oleh kepentingan-kepentingan lainya;

b. Obyektivitas, yakni pengawasan dilakukan dengan menggunakan kriteria-kriteria yang telah ditentukan sebelumnya, antara lain adalah hukum acara, peraturan perundang-undangan yang terkait, petunjuk-petunjuk Mahkamah Agung, kode etik dan pedoman perilaku (Code of Conduct) hakim;

c. Kompetensi, yakni pengawasan dilakukan oleh aparat/personil yang ditunjuk itu dengan wewenang, pertanggungjawaban, dan uraian tugas yang jelas;

d. Formalistik, yakni pengawasan dilakukan berdasarkan aturan dan mekanisme yang telah ditentukan;

e. Koordinasi, yakni pengawasan dilakukan dengan sepengetahuan pihak-pihak terkait untuk mencegah terjadinya tumpang tindih (over-lapping);

f. Integrasi dan Sinkronisasi, yakni pengawasan dilakukan dengan melibatkan pihakpihak yang terkait, untuk menghindari terjadinya tumpang tindih dalam melalukan pengawasan;

g. Efisien, Efektif, Ekonomis, pengawasan harus dilakukan dengan waktu yang cepat, biaya ringan, dan dengan hasil yang bermanfaat secara maksimal. 
Dengan memperhatikan prinsip-prinsip pengawasan tersebut, menunjukkan kesesuaian dengan apa yang telah digariskan dalam tatanan negara hukum, yang di dalamnya juga memuat nilai independensi, obyektif, efisien dan efektif. Sebagai respon dalam mengakomodir kepentingan dan kebutuhan masyarakat, khususnya berkaitan dengan pengawasan esternal, yang dilakukan oleh Komisi Yudisial, telah diterbitkan Surat Keputusan Bersama antara Ketua Mahkamah Agung RI dan Ketua Komisi Yudisial RI Nomor: 047/KMA/SK/IV/2009 - 02/SKB/P.KY/IV/2009 tanggal 8 April 2009 tentang Kode Etik dan Pedoman Perilaku Hakim. Surat Keputusan Bersama ini, merupakan jawaban atas sikap responsif MA dalam rangka menjamin terlaksananya pengawasan yang berimbang, serta tegaknya hukum dan keadilan, khususnya tercipta dan terjaganya integritas, martabat dan keluhuran hakim. Hal yang mendasar dari SKB di atas, adalah terjadi koordinasi yang bersinergi antara MA dan Komisi Yudisial, dengan dibentuknya Majelis Kehormatan Hakim (MKH) yang anggota-anggota majelisnya berasal dari kedua institusi tersebut.

Dalam setiap pengambilan putusan oleh hakim, maka hakim selalu berlindung kepada upaya hukum, yaitu Banding, Kasasi dan Peninjauan Kembali, artinya apabila Hakim Tingkat Pertama dalam memutus perkara tidak sesuai dengan norma-norma hukum yang harus dipatuhi, maka solusinya disediakan saluran untuk naik banding sebagai sarana untuk menguji putusan tersebut. Demikian pula putusan yang diambil oleh hakim tingkat banding, apabila dipandang melanggar atau keliru dalam menerapkan suatu norma hukum, pengujiannya melalui Kasasi dan seterusnya sampai pada pengujian melalui upaya Peninjauan Kembali.

Fakta empirik menunjukkan pengawasan terhadap pengambilan putusan oleh Hakim dalam memutus perkara belum begitu efektif.Mengingat belum adanya Hakim yang diproses secara pidana, karena melanggar dalam penerapan norma hukum, yang harus dipatuhi oleh Hakim dalam pengambilan suatu putusan atau dalam memutus perkara. Karena itu, penegakan hukum terhadap tindakan hakim dalam memutus perkara mutlak diperlukan terhadap para Hakim yang melanggar hukum dan kode etik yang telah ditetapkan.Sebagai contoh kasus seorang hakim babak belur, bibir pecah dan beberapa gigi retak setelah memutus perkara di Pengadilan Negeri dalam kasus pencabulan. Realitas Ini, menjadi indikator bahwa putusan yang diambil oleh hakim tersebut tidak memenuhi rasa keadilan, karena dipandang telah memihak kepada pihak tertentu, sehingga mengakibatkan peradilan yang imparsial tidak terwujud. Kasus yang terjadi ini, sebenarnya merupakan Contempt of Court sekalipun konteksnya adalah suatu bentuk protes terhadap ketidak adilan, karena keberpihakan dalam memutuskan perkara yang dilakukan oleh hakim. Penyebab utamanya, adalah belum adanya standar norma hukum yang dapat dipedomani oleh para hakim dalam pengambilan putusan dalam rangka memutus perkara. Untuk itu, agar dapat menjamin terciptanya kondisi yang kondusif bagi penyelenggara peradilan, guna menegakan hukum dan keadilan, maka perlu ditetapkan suatu undang-undang yang mengatur penindakan terhadap perbuatan, tingkah laku, sikap dan atau ucapan yang dapat merendahkan dan merongrong kewibawaan, martabat dan kehormatan badan peradilan (Contempt of Cour)". 
Dalam rencana strategis Badan Pengawasan MA mengakui sejumlah kelemahan institusinya, antara lain keterbatasan personil dan tenaga pengawas, ruang kerja dan peralatan belum memadai, tidak tersedia anggaran penanganan pengaduan yang didelegasikan badan pengawasan MA kepada pengadilan tingkat banding, dan sistem penempatan pegawai belum didasarkan pada kompetensi.Kenyataan ini, menunjukkan bahwa pengawasan yang diemban oleh MA masih kurang memadai dalam mengontrol secara internal terhadap perilaku hakim. Bahkan dipandang pengawasan MA selama ini, kurang efektif dan memiliki sejumlah kelemahan sebagai berikut :

a. Kurangnya transparansi dan akuntabilitas. Kesimpulan ini diambil dari tidak adanya mekanisme yang memberikan hak bagi pelapor untuk mengetahui laporan kemajuan (progress report) dari laporan yang dimasukkan. Selain itu, akses masyarakat terhadap proses serta hasil pengawasan sulit dilakukan;

b. Semangat membela korps sendiri yang menyebabkan pengawasan oleh MA tidak efektif. Keengganan korps hakim untuk mengangkat kasus yang melibatkan anggotanya secara tidak langsung, telah menyuburkan praktik-praktik tidak baik di pengadilan;

c. Kurang lengkapnya metode pengawasan;

d. Lemahnya sumber daya manusia, karena penentuan seseorang untuk dapat menjadi pengawas tidak diatur dalam mekanisme yang jelas. Di dalam MA seluruh Ketua Muda dan hakim agung secara ex officio menjadi pengawas;

e. Pengawasan yang berjalan selama ini, kurang melibatkan partisipasi masyarakat. Meskipun sebenarnya MA memiliki sarana untuk merangsang partisipasi masyarakat, tetapi belum dioptimalkan sarana tersebut, misalnya keberadaan kotak pos 1992 yang tidak disosialisasikan dengan baik;

f. Rumitnya birokrasi yang harus dilalui untuk melaporkan, atau mengadukan perilaku hakim yang menyimpang ${ }^{1}$.

Dengan realitas masih lemahnya pengawasan terhadap perilaku hakim selama ini, memunculkan perlunya ada pengawasan eksternal, yaitu pengawasan oleh Komisi Yudisial.Pengawasan eksternal terhadap hakim ini, diharapkan mampu menjawab berbagai problematik menyangkut kelemahan pengawasan internal oleh MA.Hal ini sangat urgen, karena dapat mendorong terciptanya sinergi antara pengawasan internal dan pengawasan eksternal. Selain itu, MA juga mengharapkan Komisi Yudisial menjadi pengawas eksternal hakim, karena MA memandang pengawas internal tak bias diharapkan, sehingga diperlukan Komisi Yudisial sebagai pengawas yang tepat untuk semua hakim, termasuk Hakim Agung. ${ }^{1}$

Berdasarkan uraian di atas, dapat disimpulkan bahwa Hakim dalam memutus perkara selalu dihadapkan pada persoalan keadilan, artinya Hakim selalu dituntut berlaku adil, dan tidak berpihak dalam memutuskan suatu perkara yang dihadapinya. Persoalan

${ }^{1}$ Mahfud, MD, Perdebatan Hukum Tata Negara Pasca Amandemen Konstitusi, LP3ES,Jakarta, 2007, HIm. 125. 
yang dihadapi Hakim untuk dapat mewujudkan suatu keadilan, adalah kasus yang diperiksa dan diputus memiliki perbedaan latar belakang, motivasi terjadinya suatu kasus dan lain-lain. Karena itu, untuk mewujudkan suatu putusan yang adil dan tidak memihak, diperlukan standar norma hukum sebagai patokan bagi para Hakim dalam memutus perkara, sehingga tidak terjadi lagi adanya Contempt of Court. Selain itu, dalam rangka penyelenggaraan kekuasaan kehakiman guna mewujudkan peradilan yang imparsial, maka pengawasan terhadap hakim menjadi sesuatu yang sangat urgen.Pengawasan itu, tidak hanya dilakukan secara internal oleh MA, tetapi juga oleh lembaga eksternal yang diselenggarakan oleh Komisi Yudisial. Dengan keterlibatan lembaga-lembaga yang diberi kewenangan untuk melakukan pengawasan, baik secara preventif maupun represif, maka upaya untuk mewujudkan peradilan yang imparsial dalam penyelenggaraan kekuasaan kehakiman akan dapat direalisasikan.

Pengawasan oleh Komisi Yudisial adalah menyangkut etika dan perilaku hakim, sedangkan Mahkamah Agung selain mengawasi etika dan perilaku hakim, juga mengawasi masalah bersifat teknik yudisial.Dengan dua pengawasan, yakni MA dan Komisi Yudisial, diharapkan perilaku dan kinerja para hakim, seperti yang diharapkan masyarakat dapat mewujudkan peradilan yang imparsial, bersih, independen dan akuntabel.Walaupun untuk mewujudkan sinergitas pengawasan antara MA dan Komisi Yudisial tidaklah mudah, mengalami pasang surut, melewati berbagai dinamika dan kendala.

Beberapa hal yang perlu dilakukan untuk membangun sistem pengawasan yang akuntabel.Pertama, perlu didorong suatu keterbukaan dalam menjalankan dan mengemukakan informasi yang bersifat material dan relevan mengenai lembaga dalam melaksanakan tugas dan wewenangnya.Informasi tersebut haruslah bersifat akurat dan aktual mengenai kinerja dari institusi kepada yustisiabel.Pada konteks ini, MA dan Komisi Yudisial dapat secara bersama merumuskan sistem keterbukaan yang lebih luas lagi pada setiap penggunaan kewenangan dan pelaksanaan program yang dilakukan oleh lembaga yudisial;Kedua, upaya-upaya untuk memastikan adanya independensi, atau kebebasan hakim perlu terus dilakukan.Independensi tetap menjadi salah satu prinsip yang sangat penting, karena harus dimaknai sebagai keadaan dimana kekuasaan kehakiman tidak hanya dibebaskan dari intervensi kekuasaan saja, tetapi juga semua faktor, pengaruh atau tekanan pihak lainnya yang bertentangan dengan integritas dan kredibilitas kekuasaan kehakiman yang baik.

\section{PENUTUP}

Berdasarkan uraian di atas, maka analisis terhadap fungsi MA dalam melakukan pengawasan peradilan yang imparsial dapat disimpulkan sebagai berikut :

1. Penyelenggaraan kekuasaan kehakiman dalam mewujudkan peradilan yang imparsial bertumpu pada adanya independensi, dan kemandirian peradilan yang dalam melaksanakan tugas yudisialnya tidak dipengaruhi oleh kekuasaan apapun, serta adanya tanggung jawab yang dibebankan kepada hakim dalam melaksanakan tugas memeriksa dan memutus perkara; dan 
2. Fungsi MA dalam pengawasan terhadap peradilan yang imparsial dalam penyelenggaraan kekuasaan kehakiman, diwujudkan dalam bentuk pengawasan preventif, berupa rambu-rambu norma yang tercantum baik dalam peraturan perundang-undangan maupun kode etik dan pedoman perilaku hakim. Selain itu, terdapat bentuk pengawasan represif yang dalam pelaksanaannya dilakukan oleh MA dan Komisi Yudisial.

\section{DAFTAR PUSTAKA}

Imam Anshori saleh, 2014, Konsep Pengawasan Kehakiman, Upaya memperkuat Kewenangan Konstitusional Komisi Yudisial Dalam Pengawasan Peradilan, Setara Press.

Mahfud, MD, 2007, Perdebatan Hukum Tata Negara Pasca Amandemen Konstitusi, LP3ES,Jakarta.

Mahkamah Agung Republik Indonesia, 2005, Naskah Akademik dan Rancangan Undang-Undang Komisi Yudisial.

Sukarno Aburaera, 2012, Kekuasaan Kehakiman Indonesia, Arus Timur, Makassar 